\title{
Increasing fruit consumption in schools in Europe
}

After three years of implementation, the European School Fruit Scheme is considered a success by the European Commission, but it can be improved, as expressed by Lars Hoelgaard, Special Advisor, DG Agriculture, European Commission: "It has been very well received by the general public in the EU. However, some Member States have not been able to fully use their allocated budget, resulting in fewer schoolchildren benefiting from the scheme. So although in the 2009/ 2010 school year, 4.7 million children have benefited from the scheme, this figure is too low",

It is the reason why the School Fruit Scheme will be reinforced. In addition, accompanying measures will be reinforced too, "to provide the link to agriculture, nutrition, bealth, the environment and physical activity, wor- king together to make the scheme much more than simply handing out fruit and vegetables to children.

The School Fruit Scheme is an investment in the future of our schoolchildren, playing its part in the fight against obesity", said Lars Hoelgaard.

Such an engagement from the European Commission is really good news and most key messages are there: the role of the school and schoolchildren as a vector of information and practices on the importance of fruits and vegetables for nutrition and health; and the need for an integrated approach linking agriculture, nutrition, health, education, the environment and physical activity.

Dr. Jacky Ganry Scientific Director of Fruits

\section{Accroitre la consommation de fruits à l'école en Europe}

Après trois ans de mise en œuvre, le programme européen en faveur de la consommation de fruits à l'école est considéré comme un succès par la Commission européenne, mais il peut être amélioré selon Lars Hoelgaard, Conseiller spécial, DG Agriculture : "Il a été très bien reçu par le public dans l'UE. Cependant, certains États membres n'ont pas été en mesure d'utiliser pleinement leur budget alloué; il en a résulté que certains écoliers ont moins bénéficié du régime. Même si pendant l'année scolaire 2009/2010, 4,7 millions d'enfants ont bénéficié de ce programme, ce chiffre est trop faible."

C'est la raison pour laquelle le programme européen en faveur de la consommation de fruits à l'école sera renforcé. En outre, les mesures d'accompagnement seront renforcées également " afin d'établir le lien avec l'agriculture, la nutrition, la santé, l'environnement et l'activité physique, travaillant ensemble pour permettre au programme d'aller beaucoup plus loin que simplement distribuer des fruits et légumes aux enfants.

Le programme européen en faveur de la consommation de fruits à l'école est un investissement pour l'avenir de nos écoliers, jouant son rôle dans la lutte contre l'obésité " a déclaré Lars Hoelgaard.

Un tel engagement de la Commission est vraiment une bonne nouvelle et la plupart des messages clés sont là : le rôle de l'école et des écoliers comme vecteur d'information et de pratiques sur l'importance des fruits et des légumes pour la nutrition et la santé ; la nécessité d'une approche intégrée qui relie l'agriculture, la nutrition, la santé, l'éducation, l'environnement et l'activité physique.
Dr. Jacky Ganry Directeur scientifique de Fruits 